\title{
PENGARUH KONSENTRASI DAN SUHU LARUTAN GULA PADA PROSES DEHIDRASI OSMOTIK BUAH NAGA (Hylocereus sp.)
}

\author{
[Effect of Concentration and Temperature of Sugar Solution in The Process of Osmotic Dehydration of \\ Dragon Fruit (Hylocereus sp.)]
}

\author{
Spetriani* \\ Program Studi Teknologi Hasil Pertanian, Fakultas Pertanian, Universitas Alkhairaat, \\ Jl. Diponegoro, Fakultas Pertanian Universitas Alkhairaat, Palu 94221, Indonesia \\ *Email: spetriani8@gmail.com
}

Diterima 7 April 2019/ Disetujui 31 Mei 2019

\begin{abstract}
Osmotic dehydration is a water removing process that carried out on a object by immersing the object into an hyper-tonic (osmotic) solution. The process is commonly applied on pre-drying of fruit. The purpose of this research is to investigate the effect of concentration and temperature of osmotic solution on moisture content change, total dissolved solids change and to determine of water diffusion coefficient and solid diffusion coefficient during the process of osmotic dehydration of dragon fruit. Factorial design was used with 2 factors, each consisting of 3 levels with 3 replication. The treatment on this research are : solution consentration of $30^{\circ} \mathrm{Brix}, 50^{\circ} \mathrm{Brix}$, and $70{ }^{\circ} \mathrm{Brix}$ and solution temperature of $30^{\circ} \mathrm{C}, 40^{\circ} \mathrm{C}$, and $50^{\circ} \mathrm{C}$ were applied to this research. The osmotic dehydration process lasts for 8 hours. Initial moisture content of dragon fruit used for the research between 511.17-665.97 (\% db). Moisture and solid diffusivities were in the range of $2.810 \times 10^{-8} \mathrm{~m}^{2} / \mathrm{s}-7.003 \times 10^{-8} \mathrm{~m}^{2} / \mathrm{s}$ and $0.973 \times 10^{-8} \mathrm{~m}^{2} / \mathrm{s}$ until $4.734 \times 10^{-8} \mathrm{~m}^{2} / \mathrm{s}$. The activation energy for diffusion of water to the concentration of $30^{\circ}$ Brix, $50{ }^{\circ}$ Brix, and $70^{\circ}$ Brix respectively is $9.963 \mathrm{~kJ} / \mathrm{mol}, 3.249$ $\mathrm{kJ} / \mathrm{mol}$, and $5.372 \mathrm{~kJ} / \mathrm{mol}$. While the activation energy for diffusion of solids is $24.946 \mathrm{~kJ} / \mathrm{mol}, 8.908 \mathrm{~kJ} / \mathrm{mol}$, and $27.343 \mathrm{~kJ} / \mathrm{mol}$.
\end{abstract}

Keywords: dragon fruit, moisture diffusivity, osmotic dehydration, solid diffusivity

\begin{abstract}
ABSTRAK
Dehidrasi osmotik adalah suatu proses pengeluaran air yang dilakukan terhadap suatu bahan dengan cara merendam bahan tersebut ke dalam suatu larutan hipertonik. Proses ini pada umumnya diaplikasikan untuk pra-pengeringan buah-buahan. Tujuan penelitian ini adalah untuk mengkaji pengaruh perlakuan konsentrasi dan suhu terhadap perubahan kadar air, perubahan total padatan terlarut dan untuk menentukan nilai koefisien difusi air dan difusi padatan selama proses dehidrasi osmotik pada buah naga. Digunakan rancangan faktorial dengan 2 faktor yang masing-masing terdiri atas 3 taraf dengan 3 kali ulangan. Perlakuan yang digunakan pada penelitian ini adalah variasi konsentrasi larutan $30^{\circ} \mathrm{Brix}, 50^{\circ} \mathrm{Brix}$, dan $70^{\circ} \mathrm{Brix}$ dan suhu larutan $30^{\circ} \mathrm{C}, 40^{\circ} \mathrm{C}$, dan $50^{\circ} \mathrm{C}$. Proses dehidrasi osmotik berlangsung selama 8 jam. Kadar air awal buah naga yang digunakan untuk

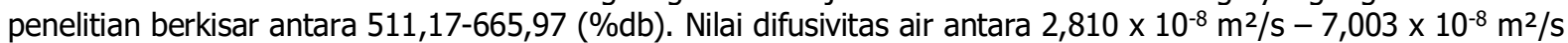
dan difusivitas padatan antara $0,973 \times 10^{-8} \mathrm{~m}^{2} / \mathrm{s}-4,734 \times 10^{-8} \mathrm{~m}^{2} / \mathrm{s}$. Energi aktivasi untuk difusi air untuk konsentrasi $30^{\circ}$ Brix, $50^{\circ}$ Brix, dan $70^{\circ}$ Brix secara berurutan adalah 9,963 kJ/mol, 3,249 kJ/mol, dan 5,372 $\mathrm{kJ} / \mathrm{mol}$. Energi aktivasi untuk difusi padatan adalah $24,946 \mathrm{~kJ} / \mathrm{mol}, 8,908 \mathrm{~kJ} / \mathrm{mol}$, dan $27,343 \mathrm{~kJ} / \mathrm{mol}$.
\end{abstract}

Kata kunci: buah naga, dehidrasi osmotik, difusivitas air, difusivitas padatan

\section{PENDAHULUAN}

Buah naga umumnya adalah buah dari beberapa jenis kaktus dari marga Hylocereus dan Selenicereus. Buah naga mulai dikenal di Indonesia sekitar pertengahan tahun 2000, yang merupakan hasil impor dari Thailand. Selain dikonsumsi dalam bentuk segar, buah naga juga sudah mulai disajikan dalam bentuk olahan. Penyajian buah naga dalam bentuk olahan industri bertujuan untuk menjaga kualitas cita rasa dan mutu produk dalam jangka waktu lama tanpa penurunan mutu. Salah satu jenis olahan buah naga adalah buah naga kering. Tujuan pengeringan ini untuk memperpanjang masa simpan buah naga, sebab buah naga termasuk salah satu buah yang mudah rusak (perishable).

Berbagai metode pengeringan yang umum dan telah lama dikenal antara lain 
Versi Online:

http://www.profood.unram.ac.id/index.php/profood e-ISSN: 2443-3446

pengeringan dengan cara dijemur maupun pengeringan menggunakan alat pengering.Terdapat perlakuan awal yang dapat diterapkan untuk mengurangi energi saat pengeringan yaitu dengan memanfaatkan tekanan osmosis. Menurut Chenlo et al. (2002), jika dua larutan dengan konsentrasi yang berbeda, yang dipisahkan oleh membran semipermeabel, cairan pelarut akan cenderung berdifusi melalui membran dari konsentrasi rendah ke larutan dengan konsentrasi yang lebih tinggi. Proses demikian disebut dengan osmosis dan energi yang mendorong terjadinya proses ini disebut tekanan osmosis.

Dehidrasi osmotik dilakukan dengan cara merendam produk ke dalam larutan gula, larutan garam, sorbitol, gliserol, dan sebagainya sebelum proses pengeringan. Proses ini biasa dilakukan dalam pembuatan produk pangan semi basah. Selanjutnya produk dikeringkan dengan penjemuran atau pengeringan buatan. Proses dehidrasi osmosis dapat digunakan untuk perlakuan pengeringan awal yang dapat menurunkan kadar air bahan sampai $50 \%$ dari kadar air awal bahan (Karathanos et al., 1995).

Metode dehidrasi osmotik dikombinasikan dengan pengeringan udara terbukti mampu menghasilkan buah kering awet dengan kadar air sekitar 14\%, sehingga kerusakan kimiawi, biologis dan enzimatis dapat dihindari. Perendaman irisan daging buah mangga kweni dalam larutan gula 60 'Brix selama 10 jam, kemudian dikeringkan pada suhu $55{ }^{\circ} \mathrm{C}$ dan kelembaban $60 \%$ selama 9 jam menghasilkan manisan mangga kweni kering, berpenampilan menarik, warna kuning merata, manis, dan memiliki kadar air optimum yaitu 14,41\% (Broto, 2003).

Pada dehidrasi osmotik buah nanas dengan larutan hipertonik $60 \%$ sukrosa selama 6 jam dengan suhu $30{ }^{\circ} \mathrm{C}, 40{ }^{\circ} \mathrm{C}$, dan $50{ }^{\circ} \mathrm{C}$ menunjukkan bahwa penurunan kadar air nanas mempunyai fungsi linier terhadap suhu perendaman. Kadar air nanas semakin turun seiring dengan peningkatan suhu larutan (Ramalo dan Mascheroni, 2005). Pada penelitian yang dilakukan oleh Jannah (2011), proses pengeringan osmotik pada mangga
Pro Food (Jurnal IImu dan Teknologi Pangan)

Vol 5 No. 1 Mei 2019

ISSN: 2443-1095

arumanis yang memiliki rasio kinerja paling baik adalah pada suhu dan konsentrasi larutan $\quad 30{ }^{\circ} \mathrm{C}$ dan $66^{\circ}$ Brix dengan sebelumnya diberi lapisan kitosan. Pada pengeringan osmotik mangga yang dilakukan oleh Azeredo et al. (2003) memperoleh rasio kinerja maksimum pada kondisi suhu $46{ }^{\circ} \mathrm{C}$ dan konsentrasi larutan 65,5 ${ }^{\circ}$ Brix. Pengeringan osmotik pada labu kuning menunjukkan peningkatan difusivitas efektif air yang signifikan ketika konsentrasi larutan gula ditingkatkan dari $40{ }^{\circ}$ Brix ke $50{ }^{\circ}$ Brix dan 60 oBrix (Abraao et al., 2013).

Tujuan penelitian ini adalah untuk (1) mengkaji pengaruh perlakuan perbedaan konsentrasi dan suhu larutan osmotik terhadap perubahan kadar air dan perubahan total padatan terlarut dan (2) mengetahui nilai koefisien difusi air dan difusi padatan selama proses dehidrasi osmotik yang dilakukan pada buah naga.

\section{BAHAN DAN METODE}

\section{Alat dan Bahan}

Penelitian dilaksanakan pada Maret 2015 di Lab. Teknik Pangan dan Pascapanen Fakultas Teknologi Pertanian, UGM, Yogyakarta. Bahan utama yang digunakan dalam penelitian adalah buah naga dan larutan osmotik berupa campuran gula dan aquades. Alat yang digunakan adalah waterbath (Neslab instrument, Inc. Newington, NH 03801 U.S.A) drying oven (Memmert, Type UM 400), refraktometer (Atago, Type cat no.3840), timbangan analitik (Shimadzu, Type AUW220), termokopel, penjepit cawan, tray, desikator, gelas ukur, pipet tetes, dan pinset.

\section{Metode dan Analisa Data}

Digunakan rancangan faktorial dengan dua faktor yang masing-masing terdiri atas 3 taraf dengan 3 kali ulangan. Dua faktor tersebut adalah konsentrasi larutan osmotik dan suhu larutan osmotik. Konsentrasi larutan osmotik yang digunakan yaitu $30^{\circ} \mathrm{Brix}, 50^{\circ} \mathrm{Brix}$, dan $70{ }^{\circ}$ Brix dengan kombinasi suhu larutan osmotik $30{ }^{\circ} \mathrm{C}, 40{ }^{\circ} \mathrm{C}$, dan $50{ }^{\circ} \mathrm{C}$. Jumlah 
Versi Online:

http://www.profood.unram.ac.id/index.php/profood e-ISSN: 2443-3446

keseluruhan perlakuan adalah 9 perlakuan dengan kombinasi seperti pada Tabel 1.

Prosedur penelitian diawali dengan pembuatan larutan osmotik dengan cara melarutkan gula (sukrosa) dalam sejumlah aquades hingga mencapai konsentrasi yang diperlukan. Larutan osmotik dalam gelas beker kemudian dimasukkan ke dalam waterbath sesuai dengan suhu yang diinginkan. Setelah itu buah naga dicuci bersih, dikupas dan dipotong dengan ukuran panjang $25 \mathrm{~mm}$, lebar $40 \mathrm{~mm}$, dan tebal $8 \mathrm{~mm}$. Potongan sampel buah naga direndam dalam larutan osmotik dan dilakukan pengukuran berat sampel dan kadar TPT dengan selang waktu pengukuran setiap 30 menit selama 8 jam.

Tabel 1. Jenis Perlakuan, kombinasi dan notasi perlakuan

\begin{tabular}{cccc}
\hline Konsentrasi & \multicolumn{3}{c}{ Suhu larutan (T) } \\
\cline { 2 - 4 } larutan (B) & $\mathbf{3 0}^{\circ} \mathbf{C}$ & $\mathbf{4 0}^{\circ} \mathbf{C}$ & $\mathbf{5 0}{ }^{\circ} \mathbf{C}$ \\
\hline $30^{\circ}$ Brix & $\mathrm{B} 1 \mathrm{~T} 1$ & $\mathrm{~B} 1 \mathrm{~T} 2$ & $\mathrm{~B} 1 \mathrm{~T} 3$ \\
$50^{\circ}$ Brix & $\mathrm{B} 2 \mathrm{~T} 1$ & $\mathrm{~B} 2 \mathrm{~T} 2$ & $\mathrm{~B} 2 \mathrm{~T} 3$ \\
$70^{\circ} \mathrm{Brix}$ & $\mathrm{B} 3 \mathrm{~T} 1$ & $\mathrm{~B} 3 \mathrm{~T} 2$ & $\mathrm{~B} 3 \mathrm{~T} 3$ \\
\hline
\end{tabular}

Parameter yang dianalisa adalah kadar air bahan menggunakan metode gravimetri (AOAC, 1995) dan kadar Total Padatan Terlarut (TPT) menggunakan alat refraktometer tipe digital. Analisis statistik yang digunakan dalam penelitian adalah analisis regresi serta uji Analysis of Variance (ANOVA) pada taraf nyata $5 \%$ dan apabila terdapat pengaruh perlakuan, maka akan diilanjut dengan uji DMRT menggunakan SPSS. Data kadar air dan TPT bahan juga diolah secara deskriptif untuk diketahui nilai difusivitas air dan difusivitas padatan serta energi aktivasinya.

Reaksi kinetika yang khas dalam alam akan terjadi pada kecepatan yang tergantung pada beberapa faktor, misalnya kecepatan dimana konsentrasi beberapa jenis komponen dikurangi akibat adanya pemanasan (Heldman dan Singh, 1981). Laju dari reaksi itu sendiri diindikasikan oleh sebuah konstanta laju. Konstanta laju perubahan beberapa komponen seperti kadar air, SG, volume, dan tekstur dihitung dengan menggunakan persamaan umum sebagai berikut.
Pro Food (Jurnal Ilmu dan Teknologi Pangan)

Vol 5 No. 1 Mei 2019

ISSN: 2443-1095

$\mathrm{n}=1$ menandakan reaksi berada pada ordo 1

$$
\begin{gathered}
\frac{d C}{d t}=-k C^{n} \\
\frac{d C}{C}=-k d t \\
\int_{0}^{t} \frac{d C}{C}=-k \int_{0}^{t} d t \\
\ln C t-\ln C 0=-k t \\
\ln \frac{C t}{C 0}=-k t \\
\frac{C t}{C 0}=\exp (-k t) \\
C t=\exp (-k t) C 0
\end{gathered}
$$

Penentuan konstanta laju penurunan kadar air dapat dievaluasi dari persamaan ordo 1 dan batas Me (kadar air keseimbangan) pada persamaan

$$
\frac{d M}{d t}=-k(M 0-M e)
$$

Sumbu $\mathrm{x}$ adalah $\mathrm{M}$ (kadar air) dan sumbu y adalah dM/dt. Dari grafik diperoleh persamaan linier sehingga nilai Me dapat dihitung dengan membagi nilai intercept dengan nilai gradien dari grafik. Persamaan di atas dapat dilinierkan sehingga menjadi persamaan

$$
\begin{aligned}
& \frac{d M}{M 0-M e}=-k d t \\
& \ln \frac{M t-M e}{M 0-M e}=-k t \\
& \frac{M t-M e}{M 0-M e}=e^{-k t} \\
M t- & M e=e^{-k t}(M 0-M e) \\
M t= & e^{-k t}(M 0-M e)+M e
\end{aligned}
$$

Hukum kedua Fick tentang model difusi (Falade et al., 2006) dapat dituliskan sebagai berikut :

$$
\begin{gathered}
\frac{M_{t-} M_{e}}{M_{0}-M_{e}}=\frac{8}{\pi^{2}} \sum_{n=1}^{\infty} \frac{1}{2 n-1} \exp \left(-(2 n-1)^{2} \frac{\pi^{2} D_{e w} t}{4 L^{2}}\right. \\
M R=\frac{M_{t-} M_{e}}{M_{0}-M_{e}}=\frac{8}{\pi^{2}} \sum_{n=1}^{\infty} \frac{1}{2 n-1} \exp \left(-(2 n-1)^{2} \frac{\pi^{2} D_{e w} t}{4 L^{2}}\right. \\
S R=\frac{S_{t-S_{e}}}{S_{0}-S_{e}}=\frac{8}{\pi^{2}} \sum_{n=1}^{\infty} \frac{1}{2 n-1} \exp \left(-(2 n-1)^{2} \frac{\pi^{2} D_{e s} t}{4 L^{2}} .\right.
\end{gathered}
$$

Persamaan tersebut dapat dilinierkan kembali, jika dilinierkan menjadi 
Versi Online:

http://www.profood.unram.ac.id/index.php/profood e-ISSN: 2443-3446

$$
\ln M R=A-B t
$$

Dimana $B=\frac{\pi^{2} D e}{4 L^{2}}$, sedang $A=\ln \frac{8}{\pi^{2}}$

Besaran dari slope B dapat dihitung dengan memplotkan In MR versus waktu ( $\mathrm{t}$ ). Hal yang sama juga dapat diterapkan untuk menghitung difusivitas solid atau padatan. Perhitungan energi aktivasi menggunakan persamaan Arrhenius.

$$
k=A e^{\frac{E a}{R T}}
$$

Jika persamaan tersebut diubah menjadi persamaan garis linier maka menjadi

$$
\ln k=\ln A-\frac{E a}{R}\left(\frac{1}{T}\right)
$$

Plot antara persamaan In $\mathrm{R}$ dengan kebalikan suhu absolut $1 / T$ akan menghasilkan slope $\mathrm{Ea} / \mathrm{R}$ sehingga nilai Ea dapat ditentukan dengan persamaan $\mathrm{Ea}=$ (a) $\mathrm{R}$ sedangkan intersepnya adalah In A sehingga nilai $A$ dapat ditentukan dari persamaan $A=\exp (b)$

\section{HASIL DAN PEMBAHASAN}

\section{Kadar Air}

Pada dehidrasi osmotik, kadar air bahan memegang peranan penting untuk menentukan sejauh mana kemampuan proses tersebut berhasil diterapkan. Pada penelitian ini kadar air pada bahan diukur sebelum perlakuan dehidrasi osmotik, selama proses dehidrasi hingga akhir proses tersebut. Nilai kadar air yang digunakan untuk perhitungan adalah kadar air basis kering (\%db). Kadar air awal bahan berkisar antara 511,17-665,97 (\%db).

Konstanta laju pengeringan bahan yang terjadi selama proses dehidrasi osmotik ditunjukkan dalam Tabel 2. Nilai konstanta laju pengeringan menunjukkan besarnya jumlah air yang keluar tiap satuan waktu.

Tabel 2. Konstanta laju pengeringan pada setiap perlakuan

\begin{tabular}{cccc}
\hline Konsentrasi & \multicolumn{3}{c}{ Suhu larutan } \\
\cline { 2 - 4 } larutan & $\mathbf{3 0}^{\circ} \mathbf{C}$ & $\mathbf{4 0}^{\circ} \mathbf{C}$ & $\mathbf{5 0}^{\circ} \mathbf{C}$ \\
\hline $30^{\circ}$ Brix & 0,0068 & 0,0043 & 0,0053 \\
$50^{\circ}$ Brix & 0,0108 & 0,0106 & 0,0100 \\
$70^{\circ}$ Brix & 0,0090 & 0,0098 & 0,0103 \\
\hline
\end{tabular}

Pro Food (Jurnal IImu dan Teknologi Pangan) Vol 5 No. 1 Mei 2019

ISSN: 2443-1095

Hasil perhitungan nilai konstanta laju pengeringan di atas dapat digunakan untuk mengetahui kadar air prediksi pada masingmasing perlakuan. Perbandingan antara besaran kadar air prediksi dan observasi dapat dilihat pada Gambar 1 sampai 3. Dari gambar grafik antara kadar air prediksi dan kadar air observasi dapat diketahui nilai koefisien determinasi $\left(R^{2}\right)$. Nilai $R^{2}$ untuk kadar air berkisar antara 0,9157-0,9797. Nilai ini menunjukkan bahwa antara hasil perhitungan kadar air prediksi dan kadar air observasi tidak jauh berbeda. Nilai $\mathrm{R}^{2}$ lebih besar dari 0,8 menunjukkan varian model bagus.

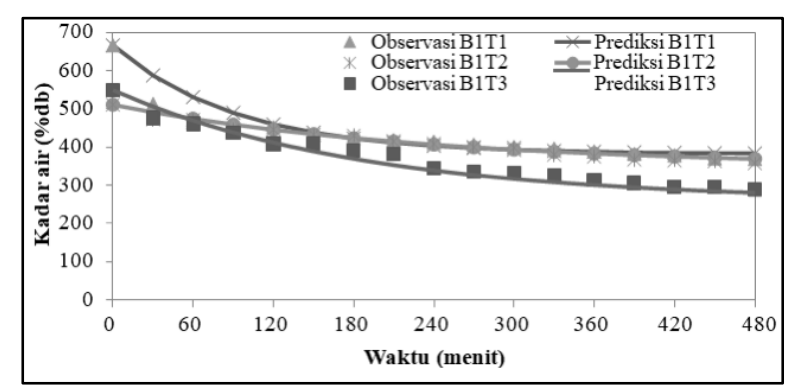

Gambar 1. Kadar air prediksi dan observasi konsentrasi $30{ }^{\circ}$ Brix

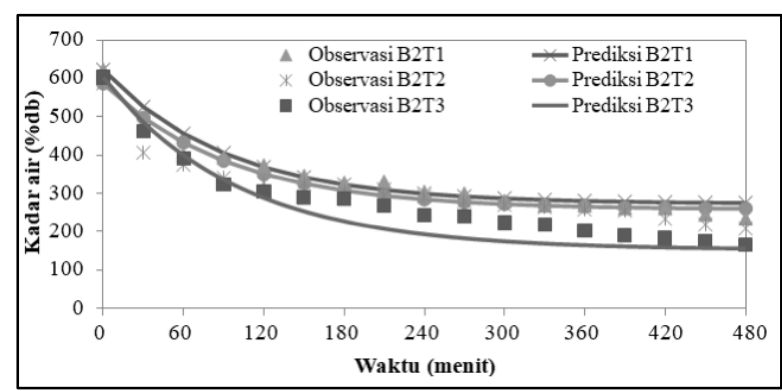

Gambar 2. Kadar air prediksi dan observasi konsentrasi $50{ }^{\circ}$ Brix

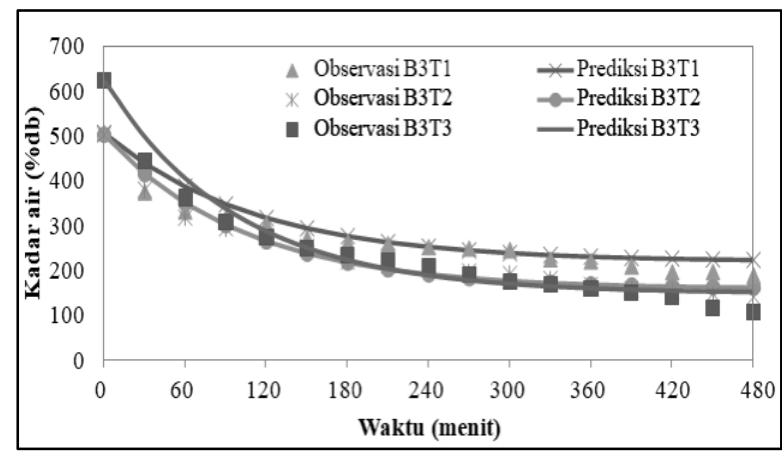

Gambar 3. Kadar air prediksi dan observasi konsentrasi $70{ }^{\circ}$ Brix

Pada gambar tersebut terlihat jelas terjadi penurunan kadar air yang polanya 
Versi Online:

http://www.profood.unram.ac.id/index.php/profood e-ISSN: 2443-3446

hampir sama pada tiap perlakuan. Kandungan air bebas dalam bahan bergerak keluar lebih cepat saat pengeringan. Pada grafik terlihat kadar air turun secara curam pada waktu awal perendaman, namun seiring waktu, gambar grafik terlihat landai pada akhir proses. Hal ini terjadi karena driving force atau gaya pendorong awal yang besar akibat perbedaan konsentrasi yang besar antara permukaan bahan dan di fasa curah. Driving force semakin menurun selama proses karena masuknya solut ke dalam bahan maupun keluarnya air dari bahan ke larutan, sampai akhirnya tercapai kondisi kesetimbangan (Witono et al., 2013).

Nilai konstanta laju pengeringan hasil perhitungan dianalisa secara statistik dengan uji anova untuk mengetahui pengaruh perbedaan perlakuan. Namun, hanya faktor konsentrasi larutan osmotik yang memiliki nilai signifikansi lebih kecil dari 0,05 (nilai signifikansi konsentrasi larutan 0,011 dan nilai signifikansi suhu larutan adalah 0,924) sehingga dinyatakan bahwa konsentrasi larutan berpengaruh terhadap nilai konstanta laju pengeringan. Hasil uji lanjut DMRT pada Tabel 3 menunjukkan bahwa nilai konstanta laju pengeringan pada konsentrasi $30^{\circ}$ Brix memiliki perbedaan yang nyata dengan konstanta pada konsentrasi $50{ }^{\circ}$ Brix dan $70{ }^{\circ} \mathrm{Brix}$

Tabel 3. Hasil uji DMRT nilai konstanta pada setiap perlakuan

\begin{tabular}{cccc}
\hline \multirow{2}{*}{ Variasi perlakuan } & \multicolumn{2}{c}{ Subset } \\
\cline { 3 - 4 } & & $\mathbf{1}$ & $\mathbf{2}$ \\
\hline Konsentrasi & $30^{\circ} \mathrm{Brix}$ & 0,0055 & \\
& $50^{\circ} \mathrm{Brix}$ & & 0,0104 \\
\multirow{4}{*}{ Suhu } & $70^{\circ} \mathrm{Brix}$ & & 0,0097 \\
& $30^{\circ} \mathrm{C}$ & 0,0088 & \\
& $40^{\circ} \mathrm{C}$ & 0,0082 & \\
& $50^{\circ} \mathrm{C}$ & 0,0085 & \\
\hline
\end{tabular}

Kadar air akhir bahan hasil dehidrasi osmotik pada masing-masing perlakuan berbeda-beda. Perubahan kadar air bahan pada setiap perlakuan dapat dilihat dalam Tabel 4 .

Tabel 4. Kadar air (ka) awal dan akhir bahan untuk setiap perlakuan
Pro Food (Jurnal Ilmu dan Teknologi Pangan)

Vol 5 No. 1 Mei 2019

ISSN: 2443-1095

\begin{tabular}{ccc}
\hline Perlakuan & $\begin{array}{c}\text { Ka awal } \\
\text { (\%odb) }\end{array}$ & $\begin{array}{c}\text { Ka akhir } \\
\text { (\%odb) }\end{array}$ \\
\hline B1T1 & 665,971 & 369,022 \\
B1T2 & 511,173 & 358,249 \\
B1T3 & 549,142 & 287,859 \\
B2T1 & 622,115 & 233,436 \\
B2T2 & 586,347 & 207,086 \\
B2T3 & 602,190 & 164,906 \\
B3T1 & 509,390 & 191,130 \\
B3T2 & 505,417 & 143,913 \\
B3T3 & 626,558 & 110,239 \\
\hline
\end{tabular}

Perubahan kadar air bahan terkecil ada pada perlakuan B1T2 dengan selisih sebesar $152,92 \%$ sedangkan perubahan kadar air terbesar terdapat pada perlakuan B3T3 dengan selisih sebesar 516,32 \%. Hal ini sejalan dengan penelitian yang dilakukan oleh Magdalena et al. (2014) yang menyatakan bahwa semakin tinggi konsentrasi larutan osmotik maka penurunan kadar air akan cenderung semakin besar.

Perhitungan uji anova dua arah (nilai signifikansi 0,001 untuk konsentrasi larutan dan 0,041 untuk suhu larutan) menunjukkan bahwa perubahan kadar air dipengaruhi oleh konsentrasi dan suhu larutan osmotik. Berdasarkan uji lanjut DMRT, perubahan kadar air pada konsentrasi $30{ }^{\circ}$ Brix berbeda nyata dengan $50{ }^{\circ}$ Brix dan 70 'Brix. Pada faktor suhu larutan, perubahan kadar air pada suhu $30{ }^{\circ} \mathrm{C}$ dan suhu $40{ }^{\circ} \mathrm{C}$ berbeda nyata dengan suhu $50{ }^{\circ} \mathrm{C}$. Hasil uji DMRT untuk perubahan kadar air ini ditampilkan pada Tabel 5.

Tabel 5. Hasil uji DMRT untuk perubahan kadar air pada setiap perlakuan

\begin{tabular}{cccc}
\hline \multirow{2}{*}{ Variasi perlakuan } & \multicolumn{2}{c}{ Subset } \\
\cline { 2 - 4 } & & $\mathbf{1}$ & $\mathbf{2}$ \\
\hline Konsentrasi & $30^{\circ} \mathrm{Brix}$ & 236,604 & \\
& $50^{\circ} \mathrm{Brix}$ & & 398,695 \\
\multirow{4}{*}{ Suhu } & $70^{\circ} \mathrm{Brix}$ & & 401,730 \\
& $30^{\circ} \mathrm{C}$ & 334,629 & 334,629 \\
& $40^{\circ} \mathrm{C}$ & 297,885 & \\
& $50^{\circ} \mathrm{C}$ & & 404,515 \\
\hline
\end{tabular}

Pada Tabel 5 dapat dilihat bahwa semakin tinggi konsentrasi dan suhu larutan osmotik, semakin tinggi pula perubahan kadar 
Versi Online:

http://www.profood.unram.ac.id/index.php/profood e-ISSN: 2443-3446

air yang dialami oleh bahan. Molekul air pada proses osmosis bergerak dari larutan hipotonik menuju larutan hipertonik dalam hal ini adalah larutan gula. Jika perbedaan konsentrasi gula semakin besar maka terjadi perbedaan tekanan osmotik yang menyebabkan perpindahan molekul air dari bahan ke larutan semakin cepat.

\section{Total Padatan Terlarut (TPT)}

Selama proses dehidrasi osmotik berlangsung terjadi perpindahan massa air dari bahan, keluar menuju larutan osmotik. Selain itu, terjadi pula perpindahan massa zat terlarut dari larutan osmotik masuk ke dalam bahan. Nilai TPT bahan diukur sebelum, selama dan sesudah proses dehidrasi osmotik berlangsung.

Nilai TPT bahan yang terukur selama proses dehidrasi osmotik digunakan untuk menghitung nilai konstanta laju peningkatan TPT. Nilai konstanta laju peningkatan kadar TPT bahan dapat dilihat pada Tabel 6. Nilai konstanta laju peningkatan TPT bahan terbesar terjadi pada perlakuan B2T3 dan B3T3. Hal ini menunjukkan bahwa semakin besar nilai konstanta semakin besar pula peningkatan kadar TPT pada bahan.

Tabel 6. Konstanta laju peningkatan TPT bahan pada setiap perlakuan

\begin{tabular}{cccc}
\hline Konsentrasi & \multicolumn{3}{c}{ Suhu larutan } \\
\cline { 2 - 4 } larutan & $\mathbf{3 0}^{\circ} \mathbf{C}$ & $\mathbf{4 0}^{\circ} \mathbf{C}$ & $\mathbf{5 0}^{\circ} \mathbf{C}$ \\
\hline $30^{\circ}$ Brix & 0,0012 & 0,0008 & 0,0013 \\
$50^{\circ}$ Brix & 0,0017 & 0,0014 & 0,0023 \\
$70^{\circ}$ Brix & 0,0009 & 0,0016 & 0,0021 \\
\hline
\end{tabular}

Nilai konstanta laju peningkatan TPT digunakan untuk menghitung kadar TPT prediksi bahan pada masing-masing perlakuan selama proses dehidrasi osmotik. Gambar perbandingan nilai TPT bahan prediksi dan observasi dapat dilihat pada Gambar 4 sampai 6. Nilai $R^{2}$ yang diperoleh untuk seluruh perlakuan berkisar antara 0,9506-0,9903. Berdasarkan hasil $\mathrm{R}^{2}$ tersebut (lebih dari 0,8 ) dapat dikatakan bahwa varian model bagus sehingga perhitungan kadar TPT prediksi dan kadar TPT observasi tidak jauh berbeda.

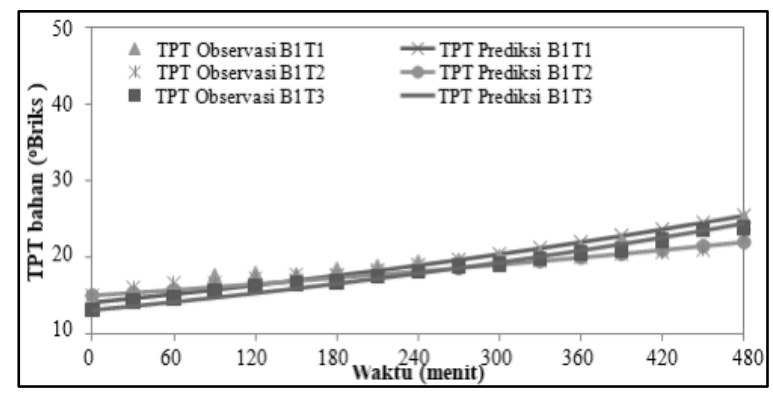

Gambar 4. Kadar TPT prediksi dan observasi konsentrasi $30^{\circ}$ Brix

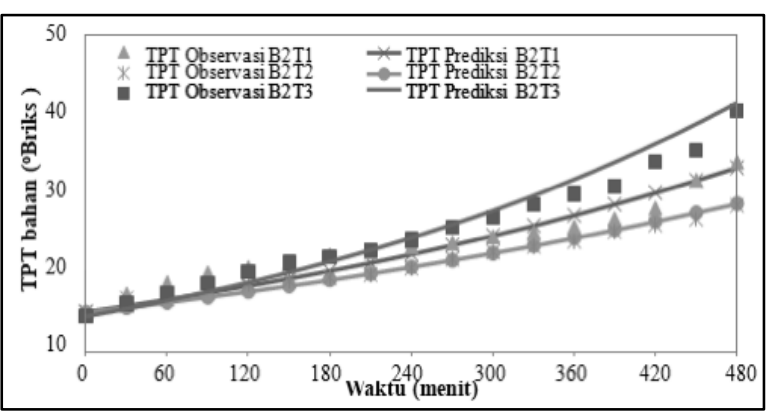

Gambar 5. Kadar TPT prediksi dan observasi konsentrasi 50 Brix

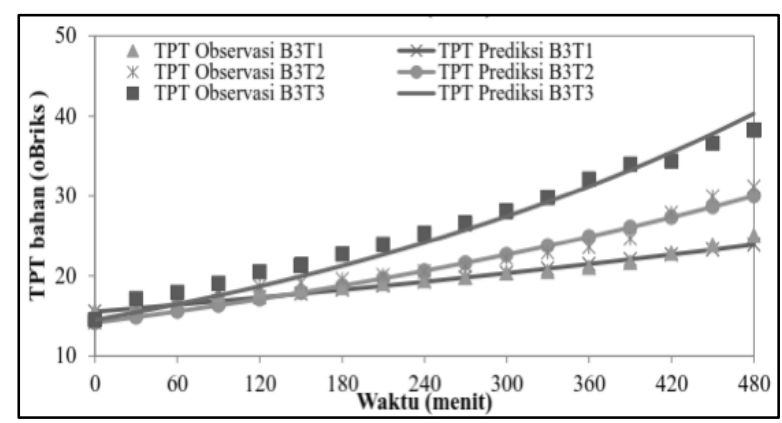

Gambar 6. Kadar TPT prediksi dan observasi konsentrasi $70{ }^{\circ} \mathrm{Brix}$

Hasil penelitian menunjukkan terjadi peningkatan TPT bahan yang seragam di semua perlakuan kecuali pada B2T3 (konsentrasi $50{ }^{\circ}$ Brix dan suhu $50{ }^{\circ} \mathrm{C}$ ) dan B3T3 (konsentrasi $70{ }^{\circ}$ Brix dan suhu $50{ }^{\circ} \mathrm{C}$ ). Pada B2T3 dan B3T3 terjadi peningkatan nilai TPT yang cukup tinggi mencapai $38,23{ }^{\circ}$ Brix dan $40,04{ }^{\circ}$ Brix. Hal ini disebabkan oleh tingginya tingkat konsentrasi serta suhu larutan osmotik yang digunakan pada perlakuan tersebut. Hal ini sesuai dengan pendapat Kartika et al. (2015) yang menyatakan bahwa peningkatan total gula seiring dengan meningkatnya konsentrasi gula dan lama perendaman. Semakin lama perendaman maka akan terjadi 
Versi Online:

http://www.profood.unram.ac.id/index.php/profood e-ISSN: 2443-3446

proses osmosis buah. Akibatnya cairan sel yang berhasil ke luar akan semakin banyak, sehingga gula reduksi dari buah dan asam organik yang ikut terbawa akan terhitung sebagai total gula.

Nilai konstanta peningkatan TPT dianalisa secara statistik dengan uji anova dua arah. Nilai signifikansi untuk konsentrasi larutan adalah 0,004 dan untuk suhu larutan adalah 0,002 . Dari hasil uji anova tersebut diperoleh bahwa tingkat konsentrasi dan suhu larutan memiliki pengaruh terhadap peningkatan kadar TPT pada bahan. Analisa kemudian dilanjutkan dengan uji lanjut DMRT. Berdasarkan uji DMRT, peningkatan TPT pada konsentrasi larutan $30{ }^{\circ}$ Brix berbeda nyata dengan konsentrasi 50 'Brix dan $70{ }^{\circ}$ Brix, sedangkan pada suhu larutan, perbedaan nyata berada antara suhu $30{ }^{\circ} \mathrm{C}$ dan $40{ }^{\circ} \mathrm{C}$ dengan suhu larutan $50^{\circ} \mathrm{C}$.

Tabel 7. Hasil uji DMRT untuk konstanta kenaikan TPT

\begin{tabular}{cccc}
\hline \multirow{2}{*}{ Variasi perlakuan } & \multicolumn{2}{c}{ Subset } \\
\cline { 2 - 4 } & & $\mathbf{1}$ & $\mathbf{2}$ \\
\hline Konsentrasi & $30^{\circ} \mathrm{Brix}$ & 0,0011 & \\
& $50^{\circ} \mathrm{Brix}$ & & 0,0018 \\
\multirow{4}{*}{ Suhu } & $70^{\circ} \mathrm{Brix}$ & & 0,0015 \\
& $30^{\circ} \mathrm{C}$ & 0,0013 & \\
& $40^{\circ} \mathrm{C}$ & 0,0013 & \\
& $50^{\circ} \mathrm{C}$ & & 0,0019 \\
\hline
\end{tabular}

\section{Difusivitas Air dan Difusivitas Padatan}

Nilai koefisien difusi air ( $D_{\text {air }}$ ) untuk setiap perlakuan bervariasi mulai dari 2,810 $\times 10-8$ hingga $7,003 \times 10-8 \mathrm{~m}^{2} / \mathrm{s}$. Koefisien difusi terkecil ada pada perlakuan B1T2 dan terbesar pada perlakuan B2T1. Nilai koefisisen difusi ini menunjukkan besarnya jumlah air yang melalui sebuah permukaan tiap satuan waktu. Selain koefisien difusi air, dilakukan juga perhitungan terhadap nilai koefisien padatan gula. Laju difusi padatan gula pada larutan osmotik lebih lambat jika dibandingkan dengan laju difusi air yang keluar dari bahan. Nilai koefisien difusi padatan ( $\left.D_{\text {solid }}\right)$ gula berkisar antara $0,973 \times 10-8 \mathrm{~m}^{2} / \mathrm{s}$ hingga $4,734 \times 10-8 \mathrm{~m}^{2} / \mathrm{s}$. Secara lengkap nilai
Pro Food (Jurnal Ilmu dan Teknologi Pangan)

Vol 5 No. 1 Mei 2019

ISSN: 2443-1095

koefisien difusi air dan koefisien difusi padatan gula disajikan dalam Tabel 8.

Tabel 8. Nilai koefisien difusi pada setiap perlakuan

\begin{tabular}{|c|c|c|c|}
\hline $\begin{array}{c}\text { Konsentrasi } \\
\text { larutan } \\
\text { ('Brix) }\end{array}$ & $\begin{array}{c}\text { Suhu } \\
\text { Larutan } \\
\left({ }^{\circ} \mathrm{C}\right)\end{array}$ & $\begin{array}{c}D_{\text {air }} \\
\left(\times 10^{-8}\right. \\
\left.\mathrm{m}^{2} / \mathrm{s}\right)\end{array}$ & $\begin{array}{l}D_{\text {solid }} \\
\left(\times 10^{-8}\right. \\
\left.\mathrm{m}^{2} / \mathrm{s}\right)\end{array}$ \\
\hline \multirow[t]{3}{*}{30} & 30 & 4,388 & 1,816 \\
\hline & 40 & 2,810 & 2,205 \\
\hline & 50 & 3,458 & 0,973 \\
\hline \multirow[t]{3}{*}{50} & 30 & 7,003 & 3,567 \\
\hline & 40 & 6,852 & 1,362 \\
\hline & 50 & 6,463 & 2,918 \\
\hline \multirow[t]{3}{*}{70} & 30 & 5,836 & 2,399 \\
\hline & 40 & 6,355 & 2,399 \\
\hline & 50 & 6,657 & 4,734 \\
\hline
\end{tabular}

Energi aktivasi adalah energi minimum yang dibutuhkan oleh partikel- partikel yang bertumbukan agar reaksi kimia tertentu dapat terjadi, dalam hal ini proses difusi air dan difusi padatan pada bahan. Besarnya nilai $D_{\text {air }}$ dan $D_{\text {solid }}$ serta variasi konsentrasi larutan mempengaruhi nilai energi aktivasi. Pada Tabel 9 disajikan besaran nilai energi aktivasi untuk $D_{\text {air }}$ dan $D_{\text {solid }}$ pada masing-masing konsentrasi larutan osmotik yang digunakan. Nilai energi aktivasi untuk difusi air cenderung mengalami penurunan seiring dengan pertambahan konsentrasi larutan osmotik.

Tabel 9. Energi aktivasi untuk difusi air dan difusi padatan selama dehidrasi osmosis

\begin{tabular}{ccc}
\hline Konsentrasi & \multicolumn{2}{c}{ Energi Aktivasi (kJ/mol) } \\
\cline { 2 - 3 } larutan ( ${ }^{\circ}$ Brix) & Dair & D solid \\
\hline 30 & 9,963 & 24,946 \\
50 & 3,249 & 8,908 \\
70 & 5,372 & 27,343 \\
\hline
\end{tabular}

\section{KESIMPULAN}

Perbedaan konsentrasi larutan dan suhu larutan memberikan pengaruh terhadap perubahan kadar air. Semakin tinggi konsentrasi dan suhu larutan osmotik, semakin besar penurunan kadar air dan peningkatan 
Versi Online:

http://www.profood.unram.ac.id/index.php/profood e-ISSN: 2443-3446

TPT yang terjadi pada buah naga. Difusivitas air meningkat seiring dengan peningkatan konsentrasi dan suhu larutan, sedangkan difusivitas padatan relatif konstan. Nilai difusivitas air hasil penelitian berkisar antara $2,810 \times 10^{-8} \mathrm{~m}^{2} / \mathrm{s}-7,003 \times 10^{-8} \mathrm{~m}^{2} / \mathrm{s}$ dan difusivitas padatan antara $0,973 \times 10^{-8} \mathrm{~m}^{2} / \mathrm{s}$ $4,734 \times 10^{-8} \mathrm{~m}^{2} / \mathrm{s}$.

\section{DAFTAR PUSTAKA}

Abraao A.S., A.M. Lemos, A. Vilela, J.M. Sousa, dan F.M. Nunes. 2013. Influence of Dehydration Process Parameters on the Quality of Candied Pumpkins. Food and Bioproduct Processing 91: 481-494.

AOAC. 1995. Official Methods of Analysis. Washington. Association of Official Analytical Chemist.

Broto, W. 2003. Mangga: Budi Daya, Pascapanen, dan Tata Niaganya. Agromedia Pustaka. Jakarta.

Falade K.O, J.C. Igbeka, dan F.A. Ayanwuyi. 2006. Kinetics of Mass Transfer, and Colour Changes during Osmotic Dehydration of Watermelon. Journal of Food Engineering 80: 979-985.

Heldman, D.R. dan R.P Singh. 1981. Food Process Engineering. $2^{\text {nd }}$ ed. The AVI Publ. Comp., Inc. Westport, CT, USA.

Jannah, M. 2011. Pengeringan Osmotik pada Irisan Buah Mangga Arumanis (Mangifera indica L.) dengan Pelapisan Kitosan. Skripsi. Fakultas Teknologi Pertanian. Institut Pertanian Bogor. Bogor.

Karathanos V.T, A.E. Kostrapoulos, dan G.D. Saravacos. 1995. Air Drying Kinetics of Osmoticaly Dehydrated Fruits. Drying Technology 13(5-7): 1503-1521.

Kartika, N.P dan F.C. Nisa. 2015. Studi Pembuatan Osmodehidrat Buah Nanas (Ananas comosus L.Merr): Kajian Konsentrasi Gula dalam Larutan Osmosis dan Lama Perendaman. Jurnal Pangan dan Agroindustri 3(4): 1345-1355.

Magdalena A., S. Waluyo, C. Sugianti. 2014. Pengaruh Suhu dan Konsentrasi Larutan Gula terhadap Proses Dehidrasi Osmosis Buah Waluh (Cucurbita moschata). J. Rekayasa Pangan dan Pert 2(4):1-8.
Pro Food (Jurnal Ilmu dan Teknologi Pangan)

Vol 5 No. 1 Mei 2019

ISSN: 2443-1095

Azeredo H.M.C, F.B.S. Araujo, A.C.R. Souza,

M.A.S. Neto, D. Garruti. 2003.

Maximization of The Performance Ratio of Osmotic Dehydration of Mango Cubes. Proc. Interamer. Soc. Trop. Hort 47: 200202.

Chenlo F., R. Moreira, C. Fernandez-Herrero, dan G. Varquez. 2002. Mass Transfer during Osmotic Dehydration of Chesnut Using Sodium Chloride Solutions. Journal of Food Engineering 73:164-173.

Ramalo, L.A., dan R.H. Mascheroni. 2005. Rate of Water Loss and Sugar Uptake During The Osmotic Dehydration of Pineapple. Brazilian Archives of Biology and Technology an International Journal 48: 761-770.

Witono J.R, Y.A. Miryanti dan L. Yuniarti. 2013. Studi Kinetika Dehidrasi Osmotik pada Ikan Teri dalam Larutan Biner dan Terner. Rekayasa Sistem Industri. 2: http://journal.unpar.ac.id/index.php/rekay asa/article/view/255 [diakses pada tanggal 1 Februari 2019] 